\title{
EVALUATION OF THE EFFECT OF MUNICIPAL SEWAGE SLUDGE COMPOST AND FURNACE WASTE ON THE QUALITY OF AMUR SILVER GRASS MISCANTHUS SACHARIFLORUS BIOMASS
}

\author{
OCENA ODDZIAŁYWANIA KOMPOSTU Z KOMUNALNEGO OSADU \\ ŚCIEKOWEGO I ODPADÓW PALENISKOWYCH NA JAKOŚĆ BIOMASY \\ MISKANTA CUKROWEGO (MISCANTHUS SACHARIFLORUS)
}

\begin{abstract}
A single-factor field experiment was carried out at the Cultivar Evaluation Station in Szczecin-Dabie in 2008-2010. The soil on which this experiment was set up is formed from light loamy sand (lls). In respect of granulometric composition, it is classified to the category of light soils, of soil quality class IV b and good rye complex. In the experiment, compost produced with municipal sewage sludge by the GWDA method was used. This compost contained clearly more nitrogen and phosphorus in relation to potassium. The content of heavy metals $(\mathrm{Cd}, \mathrm{Cu}, \mathrm{Mn}, \mathrm{Ni}, \mathrm{Pb}$ and $\mathrm{Zn})$ in composts did not exceed standards of the Regulation of the Minister of Agriculture and Rural Development (Official Journal of Laws No. 165, item 765 of 2008) referring to organic fertilisers. In the study design, the following fertilisation treatments were applied: I - carbonate lime $\left(\mathrm{CaCO}_{3}\right)$ at a dose of $1.5 \mathrm{Mg} \mathrm{CaO} \cdot \mathrm{ha}^{-1}$, II - high-calcium brown coal ash at a dose of $1.5 \mathrm{Mg} \mathrm{CaO} \cdot \mathrm{ha}^{-1}$, III - municipal sewage sludge compost at a dose of $250 \mathrm{~kg} \mathrm{~N} \cdot \mathrm{ha}^{-1}$, IV - municipal sewage sludge compost at a dose of $250 \mathrm{~kg} \mathrm{~N} \cdot \mathrm{ha}^{-1}+$ high-calcium brown coal ash at a dose of $1.5 \mathrm{Mg} \mathrm{CaO} \cdot \mathrm{ha}^{-1}$ (1st year of study), $\mathrm{V}$ - high-calcium brown coal ash at a dose of $1.5 \mathrm{Mg} \mathrm{CaO} \cdot \mathrm{ha}^{-1}$ (1st year of study), and $0.75 \mathrm{Mg} \mathrm{CaO} \cdot \mathrm{ha}^{-1}$ in following study years each, VI - municipal sewage sludge compost at a dose of $250 \mathrm{~kg} \mathrm{~N} \cdot \mathrm{ha}^{-1}+$ high-calcium brown coal ash at a dose of $1.5 \mathrm{Mg} \mathrm{CaO} \cdot \mathrm{ha}^{-1}$ (1st year of study), and $0.75 \mathrm{Mg} \mathrm{CaO} \cdot \mathrm{ha}^{-1}$ in following study years each. In addition, mineral fertilisation was applied annually in the form of multi-component fertiliser Polifoska 20, complex fertiliser Polimag S and ammonium nitrate. A test plant was perennial grass - Amur silver grass (Miscanthus sachariflorus). The obtained results show that Amur silver grass biomass contained on average the most nitrogen, ie $6.87 \mathrm{~g} \cdot \mathrm{kg}^{-1}$ d.m., in 2008 , while the most phosphorus $\left(0.39 \mathrm{~g} \mathrm{P} \cdot \mathrm{kg}^{-1} \mathrm{~d} . \mathrm{m}\right.$. $)$, potassium (7.82 $\mathrm{g} \mathrm{K} \cdot \mathrm{kg}^{-1}$ d.m.), magnesium (0.98 $\mathrm{g} \mathrm{Mg} \cdot \mathrm{kg}^{-1} \mathrm{~d} . \mathrm{m}$.) and sulphur (1.19 $\mathrm{g} \mathrm{S} \cdot \mathrm{kg}^{-1} \mathrm{~d} . \mathrm{m}$.) in 2010, whereas the most calcium ie $4.13 \mathrm{~g} \mathrm{Ca} \mathrm{kg}^{-1}$ d.m., in 2009. Significantly more nitrogen, calcium and sulphur was contained by Amur silver grass biomass from the objects where municipal sewage sludge compost had been applied without and with addition of high-calcium brown coal ash when compared to calcium carbonate or high-calcium brown coal ash being applied at a dose of $1.5 \mathrm{Mg} \mathrm{CaO} \cdot \mathrm{ha}^{-1}$. Differences in average phosphorus, potassium and magnesium contents in test plant biomass from particular fertilisation objects were not significant. The biomass of Amur silver grass contained significantly more cadmium, nickel, lead and zinc as affected by organic fertilisation without and with addition of high-calcium brown coal ash when compared with the objects where solely calcium carbonate or high-calcium brown coal ash had been introduced into soil. Differences in the average content of cadmium, nickel and zinc in test plant biomass from the objects fertilised with municipal sewage sludge compost
\end{abstract}

\footnotetext{
${ }^{1}$ Department of Land Reclamation and Environmental Chemistry, Western Pomeranian University of Technology in Szczecin, ul. J. Słowackiego 17, 71-434 Szczecin, Poland, phone +48 914496333 , email: ewa.krzywy-gawronska@zut.edu.pl
} 
without and with addition of high-calcium brown coal ash were not significant. The uptake of heavy metals by Amur silver grass biomass, $i e$ its mean value of three harvest during three years of its cultivation, can be arranged in the following descending order of values: $\mathrm{Zn}>\mathrm{Mn}>\mathrm{Pb}>\mathrm{Cu}>\mathrm{Ni}>\mathrm{Cd}$. The degree of cadmium, copper, manganese, nickel, lead and zinc bioaccumulation in test plant biomass differed, depending on the fertilisation applied. The average degree of cadmium, nickel, lead and zinc accumulation after three study years was intense for all fertilisation objects, whereas average for copper and manganese.

Keywords: compost, calcium carbonate, high-calcium brown coal ash, Amur silver grass (Miscanthus sachariflorus), macroelements, content, uptake, heavy metals bioaccumulation

\section{Introduction}

Gradual drop in the organic matter content of Polish soils and decreasing quantity of applied natural fertilisers contribute to the search for other sources of organic matter. These may be sewage sludges or composts produced with them and other structure-forming components [1-6]. The structure-forming materials in question are also a source of macro- and microelements. To remove these nuisances, the composting of municipal sewage sludge with addition of structure-forming materials containing organic matter (straw, sawdust) is being applied. As a result of this process, the obtained compost (organic fertiliser) is stabilised and hygienised [7-10].

They can be used for fertilisation of cultivated plants provided that they do not contain excessive amounts of heavy metals and are not microbially contaminated $[5,11,12]$. The content of these chemical elements in soil and plant needs to be constantly examined since their dangerous levels may be accessible through plant diet to animals without symptoms of harmful effect on plants $[13,14]$. Brown and hard coal ashes are differently evaluated due to their specific physicochemical and biological properties. Diversified chemical composition of ashes results from different characteristics of combusted hard coal. This makes ashes with constant quality impossible to obtain, which in turn makes their use difficult. These difficulties may be eliminated through mixing ashes with municipal sewage sludges or with composts being produced with them, composting them with brown coal or sewage sludge addition, or their partial hydration [15].

Some authors are of the opinion that ashes should not be used for ecological purposes because of the content of heavy metals and other toxic components [16-17]. Other authors claim that these wastes are being characterised by the features which favourably affect soil environment, eg through deacidification, supply of nutrients or improvement of plant habitat $[18,19]$.

As a rule, furnace ash (waste) contains smaller amount of heavy metals than municipal sewage sludge [20]. In ash-sludge mixtures, $\mathrm{pH}$ value increases together with an increase in ash percentage. The reaction corresponding to a $\mathrm{pH}$ value of 10-11 contributes to a decrease in the solubility of heavy metals [21]. Furnace ashes are characterised by poor storage capacity and alkaline reaction and therefore can be used to bind heavy metals which are to be found in sewage sludges or composts produced with them and the same can limit their availability for plants [22].

By-product being developed during technological processes of coal combustion is ashes which contain chemical elements required by plants for their growth and development [23]. The problem of proper furnace waste management in Poland and other countries 
producing electric energy from coal combustion has become a subject of intensive scientific research. This is connected with a need to protect areas of their storage against dusting and migration of heavy metals to subsoil and to improve hygienic and aesthetic environmental conditions [15].

Over the last decade, numerous studies have been carried out in Europe on the cultivation of Amur silver grass (Miscanthus sachariflorus), the biomass of which is being intended for renewable energy harvesting. It is characterised by considerable tolerance to diversified levels of macro- and microelements, including also heavy metals. To obtain large quantity of Amur silver grass biomass, optimum fertilisation is required. Nutrients can be supplied, among others, in the form of composts produced with sewage sludge and other wastes, $e g$ high-calcium brown coal ash.

The objective of carried out study was to determine the effect of compost produced with municipal sewage sludge by the GWDA method (organic fertiliser) and high-calcium brown coal ash (furnace waste) as a fertiliser for soil deacidification on the content of macroelements and heavy metals. The uptake dynamics of heavy metals and their bioaccumulation in Amur silver grass biomass during a three-year field experiment was evaluated.

\section{Material and research methods}

While executing the study objective in 2008-2010, a single-factor field experiment was set up at the Cultivar Evaluation Station in Szczecin-Dabie. The soil on which this experiment was set up had been formed from light loamy sand (lls). In respect of granulometric composition, it is classified into the category of light soils, of soil quality class IV $\mathrm{b}$ and good rye complex.

After introducing the compost with municipal sewage sludge, calcium carbonate and high-calcium brown coal ash into soil in spring 2008, the following mineral fertilisation was applied: $42.5 \mathrm{~kg} \mathrm{~N} \cdot \mathrm{ha}^{-1}$ was introduced into soil in the form of ammonium nitrate in the first year of experiment (2008) prior to sowing test plants, as well as $28 \mathrm{~kg} \mathrm{P} \cdot \mathrm{ha}^{-1}$ and $66.4 \mathrm{~kg} \mathrm{~K} \cdot \mathrm{ha}^{-1}$ in the form of multicomponent fertiliser Suprofoska 20 (400 kg fertiliser per ha). Thereafter, test plant seedlings were planted. Six weeks after planting Amur silver grass seedlings, $42.5 \mathrm{~kg} \mathrm{~N} \cdot \mathrm{ha}^{-1}$ was introduced into soil in the form of ammonium nitrate as the top dressing. In the second year of experiment (2009), a complex fertiliser Polimag S was introduced into soil in spring at an $800 \mathrm{~kg} \cdot \mathrm{ha}^{-1}$ dose. This corresponded to $80 \mathrm{~kg} \mathrm{~N} \cdot \mathrm{ha}^{-1}, 28 \mathrm{~kg} \mathrm{P} \cdot \mathrm{ha}^{-1}, 100 \mathrm{~kg} \mathrm{~K} \cdot \mathrm{ha}^{-1}, 24 \mathrm{~kg} \mathrm{Mg} \cdot \mathrm{ha}^{-1}$ and $112 \mathrm{~kg} \mathrm{~S} \cdot \mathrm{ha}^{-1}$. In addition, this fertiliser contained copper, zinc, boron and manganese. In the third year of experiment (2010), a complex fertiliser Polimag S was introduced into soil in spring at the same dose as in 2009. In the second and third year of carrying out the experiment, $34 \mathrm{~kg} \mathrm{~N} \cdot \mathrm{ha}^{-1}$ was introduced into soil eight weeks after application of complex fertiliser Polimag $\mathrm{S}$ in the form of ammonium nitrate. High-calcium brown coal ash was introduced into soil in the objects with annual application in April 2009 and 2010.

A test plant was Amur silver grass (Miscantus saccharflorus), which was harvested after 219 days of vegetation in the first year of experiment, 181 days in the second year and 187 days in the third year.

The compost with municipal sewage sludge used in the experiment, produced by the GWDA method at the Municipal Sewage Treatment Plant in Stargard Szczecinski, 
corresponded, in respect to its chemical composition, to the standards allowing it to be classified into the group of organic fertilisers [24]. This compost had a $\mathrm{pH}_{\mathrm{H} 2 \mathrm{O}}$ of 8.50 and therefore can be applied without fear on strongly acid and acid soils which constitute more than $50 \%$ in Poland [25]. The total content of nitrogen $\left(18 \mathrm{~g} \mathrm{~N} \cdot \mathrm{kg}^{-1}\right.$ d.m.) and phosphorus (10.2 $\mathrm{g} \mathrm{P} \cdot \mathrm{kg}^{-1}$ d.m.) in this compost was clearly higher than that of potassium (3.58 $\mathrm{g} \mathrm{K} \cdot \mathrm{kg}^{-1}$ d.m.). Therefore, deficiencies of this chemical element in it should be supplemented with potassium mineral fertilisers. An important factor of composting is to obtain an optimal $\mathrm{C}: \mathrm{N}$ ratio, the values of which are within the range of 20-30:1 according to different authors [26, 27]. The $\mathrm{C}: \mathrm{N}$ ratio in the compost being used in this study amounted to 10.9 and was slightly narrow. Similar study results were obtained when composting sewage sludge with rice straw (C:N ratio was 10.6) or plant wastes $(\mathrm{C}: \mathrm{N}$ ratio was 9.8) $[8,28]$.

The high-calcium brown coal ash used in the study came from the Patnow-Adamow-Konin Power Plant Complex. It contained more potassium (5.50 $\mathrm{g} \cdot \mathrm{kg}^{-1}$ d.m.) than phosphorus (2.52 $\mathrm{g} \cdot \mathrm{kg}^{-1}$ d.m.). This ash partly supplemented potassium deficiency in the compost. It was characterised by high value of $\mathrm{pH}_{\mathrm{KCl}}$ (11.0) and contained $986 \mathrm{~g} \cdot \mathrm{kg}^{-1}$ dry matter as well as $145 \mathrm{~g} \mathrm{Ca} \cdot \mathrm{kg}^{-1}$ d.m. and $12.5 \mathrm{~g} \mathrm{Mg} \cdot \mathrm{kg}^{-1} \mathrm{~d}$.m. No nitrogen or organic carbon was found in the ash [29].

High calcium content in the ash used in this study ( $145 \mathrm{~g} \mathrm{Ca} \cdot \mathrm{kg}^{-1} \mathrm{~d} . \mathrm{m}$.) allowed it to be classified into the group of high-calcium ashes. The total content of cadmium $\left(2.77 \mathrm{mg} \cdot \mathrm{kg}^{-1}\right)$, manganese $\left(265 \mathrm{mg} \cdot \mathrm{kg}^{-1}\right)$, nickel $\left(12.6 \mathrm{mg} \cdot \mathrm{kg}^{-1}\right)$, zinc $\left(231.0 \mathrm{mg} \cdot \mathrm{kg}^{-1}\right)$ and chromium $\left(20.6 \mathrm{mg} \cdot \mathrm{kg}^{-1}\right)$ in the examined high-calcium brown coal ash was higher than in municipal sewage sludge compost. On the other hand, copper and lead contents (27.6 and 16.2 in $\mathrm{mg} \cdot \mathrm{kg}^{-1}$, respectively) were higher in the compost when compared with highcalcium brown coal ash. Taking into consideration the standards referring to the content of heavy metals in fertilisers for soil deacidification [26], high-calcium brown coal ash may by included among the factors affecting soil deacidification without negative environmental impact.

The soil on which the experiment was set up was characterised by acidic reaction $\left(\mathrm{pH}_{\mathrm{KCl}} 5.30\right)$, which was an indication to carry out liming. The content of macroelements was below average when compared witho mean values for that type of soils. The content of assimilable phosphorus forms was low $\left(24.8 \mathrm{mg} \cdot \mathrm{kg}^{-1} \mathrm{~d} . \mathrm{m}\right.$.), while that of potassium and magnesium was average (120.0 and $47.0 \mathrm{mg} \cdot \mathrm{kg}^{-1} \mathrm{~d} . \mathrm{m}$., respectively). The content of organic carbon in soil was low and amounted to $8.50 \mathrm{~g} \cdot \mathrm{kg}^{-1} \mathrm{~d} . \mathrm{m}$. The carbon-to-nitrogen ratio $(\mathrm{C}: \mathrm{N})$ was 11.8: 1 and was average for that type of soils [29]. The content of microelements in soil, including heavy metals, did not exceed the limits for light soils being reported. In the light of legislation in force, examinations with municipal sewage sludge composts and highcalcium brown coal ash could be carried out on such a soil.

The content of macroelements in Amur silver grass biomass in successive study years was determined in average samples from four replications of each fertilisation object. The nitrogen content was determined by Kjeldahl method (PN ISO 13878), the phosphorus content by the colorimetric method according to Barton and that of sulphur by means of the nefelometric method on a Perkin Elmer Lambda EZ 150 apparatus, while potassium, magnesium and calcium contents by the method of atomic absorption spectrometry (AAS) on a Perkin Elmer AAS 300 spectrometer. The stock solution was obtained after previous wet mineralisation of plant material according to the Polish standards PN-ISO 11466 and 
PN-ISO 11047. Cadmium, copper, manganese, nickel, lead and zinc contents were determined by the method of atomic absorption spectrometry on a Perkin Elmer AAS 300 spectrometer. The stock solution was obtained after wet mineralisation of plant material according to the Polish standards PN-ISO 11466 and PN-ISO 11047.

The content of macroelements was processed statistically by the analysis of variance method according to Statistica 8.0 PL computer software package. In case of significant differences, the Tukey's test was used at significance level $\mathrm{p}=0.05$.

Cadmium, copper, manganese, nickel, lead and zinc bioaccumulation factors were calculated as a ratio of the content of a given chemical element to the doses introduced into soil with municipal sewage sludge compost and high-calcium brown coal ash [30].

When evaluating the bioaccumulation factors, a four-point scale of heavy metals accumulation. Bioaccumulation factors and corresponding degrees of accumulation for heavy metals in plants are given below [31]:

\begin{tabular}{cc}
$\begin{array}{c}\text { Bioaccumulation factor } \\
0.001-0.01\end{array}$ & $\begin{array}{c}\text { Degree of accumulation } \\
\text { none }\end{array}$ \\
\hline $0.01-0.1$ & poor \\
\hline $0.1-1.0$ & average \\
\hline $1.0-10.0$ & intense
\end{tabular}

\section{Results and discussion}

The results obtained in this study are presented in Tables 1-6. Amur silver grass biomass contained on average the most nitrogen in $2008\left(6.87 \mathrm{~g} \cdot \mathrm{kg}^{-1} \mathrm{~d}\right.$.m. $)$, while the most phosphorus, potassium, magnesium and sulphur in $2010(0.39,7.82,0.98$ and $1.19 \mathrm{~g} \cdot \mathrm{kg}^{-1}$ d.m., respectively) and the most calcium in $2009\left(4.13 \mathrm{~g} \cdot \mathrm{kg}^{-1} \mathrm{~d}\right.$.m.). Contents of nitrogen, phosphorus and magnesium in Amur silver grass biomass obtained in the present study were average, whereas that of potassium was low [32, 33]. As a rule, the content of chemical elements under discussion was higher in the biomass of test plant from the objects where organic fertilisation had been applied without and with addition of high-calcium brown coal ash (fertilisation objects III, IV and VI) when compared with those where municipal sewage sludge compost had not been applied (fertilisation objects I, II and V). However, differences in the average content of macroelements in Amur silver grass biomass were not always significant (Tables 1 and 2).

Amur silver grass biomass from the objects where organic fertilisation had been applied without and with addition of high-calcium brown coal ash $\left(6.44\right.$ and $\left.6.61 \mathrm{~g} \cdot \mathrm{kg}^{-1}\right)$ contained significantly more nitrogen when compared with that where carbonate lime or high-calcium brown coal ash had been introduced into soil at a dose of $1.5 \mathrm{Mg} \mathrm{CaO} \cdot \mathrm{ha}^{-1}$ (5.63 $\mathrm{g} \cdot \mathrm{kg}^{-1}$ and $5.51 \mathrm{~g} \cdot \mathrm{kg}^{-1}$, respectively), being applied in the first year of study. Differences in average nitrogen content in the biomass of test plants from the objects with municipal sewage sludge compost without and with addition of high-calcium brown coal ash were not significant. No significant differences were observed either in average nitrogen content in Amur silver grass biomass between the objects where only calcium carbonate or high-calcium brown coal ash had been introduced into soil (Table 1). Average increase in the nitrogen content in test plant biomass between the objects where municipal sewage sludge compost without and with addition of high-calcium brown coal ash had been 
introduced into soil amounted respectively to 18.1 and $15.6 \%$ when compared with high-calcium brown coal ash or calcium carbonate.

Macroelements content in Amur silver grass biomass in $\left[\mathrm{g} \cdot \mathrm{kg}^{-1} \mathrm{~d} . \mathrm{m}.\right]$

Table 1

\begin{tabular}{|c|c|c|c|c|}
\hline \multirow{3}{*}{ Fertilisation objects } & \multirow{3}{*}{$\begin{array}{l}\text { Study } \\
\text { years }\end{array}$} & \multicolumn{3}{|c|}{ Chemical element } \\
\hline & & $\mathbf{N}$ & $\mathbf{P}$ & $\mathbf{K}$ \\
\hline & & \multicolumn{3}{|c|}{$\left[\mathrm{g} \cdot \mathrm{kg}^{-1}\right.$ d.m. $]$} \\
\hline \multirow{3}{*}{ I. Carbonate lime $\left(\mathrm{CaCO}_{3}\right)$ at a dose of $1.5 \mathrm{Mg} \mathrm{CaO} \cdot \mathrm{ha}^{-1}$} & 2008 & 6.32 & 0.23 & 6.84 \\
\hline & 2009 & 5.17 & 0.24 & 6.30 \\
\hline & 2010 & 5.40 & 0.32 & 10.6 \\
\hline \multicolumn{2}{|l|}{ Mean value } & 5.63 & 0.26 & 7.91 \\
\hline \multirow{3}{*}{$\begin{array}{l}\text { II. High-calcium brown coal ash at a dose } \\
\text { of } 1.5 \mathrm{Mg} \mathrm{CaO} \cdot \mathrm{ha}^{-1}\end{array}$} & 2008 & 6.25 & 0.27 & 6.92 \\
\hline & 2009 & 5.06 & 0.24 & 6.42 \\
\hline & 2010 & 5.22 & 0.33 & 7.02 \\
\hline \multicolumn{2}{|l|}{ Mean value } & 5.51 & 0.28 & 6.78 \\
\hline \multirow{3}{*}{$\begin{array}{l}\text { III. Municipal sewage sludge compost at a dose } \\
\text { of } 250 \mathrm{~kg} \mathrm{~N} \cdot \mathrm{ha}^{-1}\end{array}$} & 2008 & 7.42 & 0.33 & 7.43 \\
\hline & 2009 & 6.02 & 0.42 & 6.65 \\
\hline & 2010 & 5.87 & 0.48 & 7.25 \\
\hline \multicolumn{2}{|l|}{ Mean value } & 6.44 & 0.41 & 7.11 \\
\hline IV. Municipal sewage sludge compost at a dose & 2008 & 7.45 & 0.33 & 7.55 \\
\hline of $250 \mathrm{~kg} \mathrm{~N} \cdot \mathrm{ha}^{-1}+$ high-calcium brown coal ash at a dose & 2009 & 6.40 & 0.40 & 6.98 \\
\hline of $1.5 \mathrm{Mg} \mathrm{CaO} \cdot \mathrm{ha}^{-1}(1$ st year of study) & 2010 & 5.98 & 0.52 & 7.25 \\
\hline \multicolumn{2}{|l|}{ Mean value } & 6.61 & $\mathbf{0 . 4 2}$ & 7.26 \\
\hline V. High-calcium brown coal ash at a dose & 2008 & 6.35 & 0.28 & 7.03 \\
\hline of $1.5 \mathrm{Mg} \mathrm{CaO} \cdot \mathrm{ha}^{-1}$ (1st year of study), & 2009 & 5.12 & 0.29 & 6.58 \\
\hline and $0.75 \mathrm{Mg} \mathrm{CaO} \cdot \mathrm{ha}^{-1}$ in following study years each & 2010 & 5.72 & 0.36 & 7.35 \\
\hline \multicolumn{2}{|l|}{ Mean value } & 5.73 & 0.31 & 6.98 \\
\hline \multirow{3}{*}{$\begin{array}{l}\text { VI. Municipal sewage sludge compost at a dose of } \\
250 \mathrm{~kg} \mathrm{~N} \cdot \mathrm{ha}^{-1}+\text { high-calcium brown coal ash at a dose } \\
\text { of } 1.5 \mathrm{Mg} \mathrm{CaO} \cdot \mathrm{ha}^{-1} \text { (1st year of study), } \\
\text { and } 0.75 \mathrm{Mg} \mathrm{CaO} \cdot \mathrm{ha}^{-1} \text { in following study years each }\end{array}$} & 2008 & 7.48 & 0.24 & 7.65 \\
\hline & 2009 & 6.10 & 0.48 & 7.13 \\
\hline & 2010 & 5.90 & 0.35 & 7.48 \\
\hline \multicolumn{2}{|l|}{ Mean value } & 6.49 & 0.36 & 7.42 \\
\hline \multicolumn{2}{|l|}{$\mathbf{L S D}_{\mathbf{0 . 0 5}}$} & 0.641 & n.s. & n.s. \\
\hline
\end{tabular}

On average, the most phosphorus $\left(0.41,0.42\right.$ and $0.36 \mathrm{~g} \cdot \mathrm{kg}^{-1} \mathrm{~d} . \mathrm{m}$.) was contained by Amur silver grass biomass from the objects where municipal sewage sludge compost without and with addition of high-calcium brown coal ash had been introduced into soil when compared with calcium carbonate $\left(0.26 \mathrm{~g} \cdot \mathrm{kg}^{-1}\right)$ and high-calcium brown coal ash $\left(0.28 \mathrm{~g} \cdot \mathrm{kg}^{-1}\right)$ being introduced into soil at the beginning of the this study and in following study years $\left(0.31 \mathrm{~g} \cdot \mathrm{kg}^{-1}\right)$. Differences in average phosphorus content in test plant biomass being harvested from respective fertilisation objects were not significant (Table 1). Despite the lack of significant differences, an increase was found in the phosphorus content in Amur silver grass biomass, respectively by 50 and $32.2 \%$, between the objects where municipal sewage sludge compost without and with high-calcium brown coal ash had been introduced into soil when compared with calcium carbonate and high-calcium brown coal ash being applied at the beginning of study and annually.

The highest average potassium content was found in the object with calcium carbonate $\left(7.91 \mathrm{~g} \cdot \mathrm{kg}^{-1}\right)$ and municipal sewage sludge compost with addition of high-calcium brown coal ash being applied annually $\left(7.42 \mathrm{~g} \cdot \mathrm{kg}^{-1}\right)$ when compared with the objects being 
fertilised with high-calcium brown coal ash in the first year of study and in following study years $\left(6.78\right.$ and $\left.6.98 \mathrm{~g} \cdot \mathrm{kg}^{-1}\right)$ - see Table 1 .

Table 2

Calcium, magnesium and sulphur content in Amur silver grass biomass in $\left[\mathrm{g} \cdot \mathrm{kg}^{-1} \mathrm{~d} . \mathrm{m}.\right]$

\begin{tabular}{|c|c|c|c|c|}
\hline \multirow{3}{*}{ Fertilisation objects } & \multirow{3}{*}{$\begin{array}{l}\text { Study } \\
\text { years }\end{array}$} & \multicolumn{3}{|c|}{ Chemical element } \\
\hline & & $\mathbf{C a}$ & Mg & $\mathbf{S}$ \\
\hline & & \multicolumn{3}{|c|}{$\left[\mathrm{g} \cdot \mathrm{kg}^{-1}\right.$ d.m. $]$} \\
\hline \multirow{3}{*}{ I. Carbonate lime $\left(\mathrm{CaCO}_{3}\right)$ at a dose of $1.5 \mathrm{Mg} \mathrm{CaO} \cdot \mathrm{ha}^{-1}$} & 2008 & 3.25 & 0.65 & 0.90 \\
\hline & 2009 & 3.46 & 0.72 & 0.71 \\
\hline & 2010 & 3.60 & 0.92 & 0.98 \\
\hline \multicolumn{2}{|l|}{ Mean value } & 3.44 & 0.76 & 0.86 \\
\hline \multirow{3}{*}{$\begin{array}{l}\text { II. High-calcium brown coal ash at a dose of } \\
\qquad 1.5 \mathrm{Mg} \mathrm{CaO} \cdot \mathrm{ha}^{-1}\end{array}$} & 2008 & 3.46 & 0.67 & 0.94 \\
\hline & 2009 & 3.49 & 0.75 & 0.75 \\
\hline & 2010 & 3.68 & 0.86 & 1.15 \\
\hline \multicolumn{2}{|l|}{ Mean } & 3.54 & 0.76 & 0.94 \\
\hline \multirow{3}{*}{$\begin{array}{l}\text { III. Municipal sewage sludge compost at a dose of } \\
\qquad 250 \mathrm{~kg} \mathrm{~N} \cdot \mathrm{ha}^{-1}\end{array}$} & 2008 & 4.15 & 0.69 & 1.36 \\
\hline & 2009 & 4.26 & 0.91 & 0.95 \\
\hline & 2010 & 3.95 & 1.08 & 1.10 \\
\hline \multicolumn{2}{|l|}{ Mean value } & 4.12 & 0.89 & 1.14 \\
\hline \multirow{3}{*}{$\begin{array}{c}\text { IV. Municipal sewage sludge compost at a dose of } \\
250 \mathrm{~kg} \mathrm{~N} \cdot \mathrm{ha}^{-1}+\text { high-calcium brown coal ash at a dose of } \\
1.5 \mathrm{Mg} \mathrm{CaO} \cdot \mathrm{ha}^{-1} \text { (1st year of study) }\end{array}$} & 2008 & 4.25 & 0.70 & 1.28 \\
\hline & 2009 & 4.94 & 0.92 & 0.97 \\
\hline & 2010 & 5.21 & 1.09 & 1.39 \\
\hline \multicolumn{2}{|l|}{ Mean value } & 4.80 & 0.90 & 1.21 \\
\hline \multirow{3}{*}{$\begin{array}{c}\text { V. High-calcium brown coal ash at a dose of } \\
1.5 \mathrm{Mg} \mathrm{CaO} \cdot \mathrm{ha}^{-1} \text { (1st year of study), and } 0.75 \mathrm{Mg} \mathrm{CaO} \cdot \mathrm{ha}^{-1} \\
\text { in following study years each }\end{array}$} & 2008 & 4.05 & 0.67 & 0.88 \\
\hline & 2009 & 3.55 & 0.87 & 0.70 \\
\hline & 2010 & 3.25 & 0.96 & 1.24 \\
\hline \multicolumn{2}{|l|}{ Mean value } & 3.62 & 0.83 & 0.94 \\
\hline \multirow{3}{*}{$\begin{array}{c}\text { VI. Municipal sewage sludge compost at a dose of } \\
250 \mathrm{~kg} \mathrm{~N} \cdot \mathrm{ha}^{-1}+\text { high-calcium brown coal ash at a dose of } \\
1.5 \mathrm{Mg} \mathrm{CaO} \cdot \mathrm{ha}^{-1} \text { (1st year of study), and } 0.75 \mathrm{Mg} \mathrm{CaO} \cdot \mathrm{ha}^{-1} \\
\text { in following study years each }\end{array}$} & 2008 & 4.60 & 0.72 & 1.31 \\
\hline & 2009 & 5.06 & 0.84 & 0.98 \\
\hline & 2010 & 4.67 & 1.02 & 1.29 \\
\hline \multicolumn{2}{|l|}{ Mean value } & 4.78 & 0.86 & 1.19 \\
\hline \multicolumn{2}{|l|}{$\mathbf{L S D}_{0.05}$} & 1.14 & n.s. & 0.310 \\
\hline
\end{tabular}

Differences in average potassium content in test plant biomass harvested from respective fertilisation objects were not significant (Table 1). However, despite the lack of significant differences in the potassium content in test plant biomass, a decrease was found in its content between the object where carbonate lime had been introduced into soil at a dose of $1.5 \mathrm{Mg} \mathrm{CaO} \cdot \mathrm{ha}^{-1}$ when compared with other objects (fertilisation objects II, III, IV, V and VI), respectively by $14.3,10.1,8.22,11.7$ and $6.20 \%$.

On average, the most calcium was contained by Amur silver grass biomass from the objects being fertilised with municipal sewage sludge compost without and with addition of high-calcium brown coal ash introduced into soil at the beginning of study and annually $\left(4.12,4.80\right.$ and $4.78 \mathrm{~g} \cdot \mathrm{kg}^{-1} \mathrm{~d}$.m.). Average calcium content in test plant biomass from these objects was significantly higher when compared with those where calcium carbonate or high-calcium brown coal ash had been applied at a dose of $1.5 \mathrm{Mg} \mathrm{CaO} \cdot \mathrm{ha}^{-1}$ (3.44 and $3.54 \mathrm{~g} \cdot \mathrm{kg}^{-1}$ d.m., respectively) in the first year of study. Differences in its average content in Amur silver grass biomass from the objects where calcium carbonate or high-calcium brown coal ash had been applied were not significant (Table 2). 
The highest average magnesium content was found in test plant biomass from fertilisation objects III, IV and V $\left(0.89,0.89\right.$ and $0.86 \mathrm{~g} \cdot \mathrm{kg}^{-1} \mathrm{~d} . \mathrm{m}$., respectively). On the other hand, its average content in Amur silver grass biomass in the objects with carbonate lime and high-calcium brown coal ash was at the same level and amounted to $0.76 \mathrm{~g} \cdot \mathrm{kg}^{-1}$ d.m. Differences in average magnesium content in test plant biomass from respective fertilisation objects were not significant (Table 2). Despite the lack of significant differences, an average increase was found in the magnesium content in test plant biomass between the objects where municipal sewage sludge compost without and with addition of high-calcium brown coal ash had been introduced into soil when compared with calcium carbonate and high-calcium brown coal ash being applied at a dose of $1.5 \mathrm{Mg} \mathrm{CaO} \cdot \mathrm{ha}^{-1}$ in the first year of study and $0.75 \mathrm{Mg} \mathrm{CaO} \cdot \mathrm{ha}^{-1}$ in following study years, respectively by 15.8 and $5.68 \%$.

On average, the most sulphur was contained by Amur silver grass biomass from the objects being fertilised with municipal sewage sludge compost and high-calcium brown coal ash applied in the first year of study and annually $\left(1.14,1.21\right.$ and $1.19 \mathrm{~g} \cdot \mathrm{kg}^{-1} \mathrm{~d} . \mathrm{m}$.). Average sulphur content in Amur silver grass biomass from the fertilisation objects mentioned above was significantly higher when compared with that where only calcium carbonate had been applied $\left(0.86 \mathrm{~g} \cdot \mathrm{kg}^{-1}\right.$ d.m. $)$. This increase amounted to $37.2 \%$. Differences in the sulphur content in test plant biomass between other fertilisation objects were not significant (Table 2).

Decidedly more nitrogen, phosphorus, calcium, magnesium and sulphur was contained by Amur silver grass in the objects where municipal sewage sludge compost and high-calcium brown coal ash had been applied when compared with those where organic fertilisation had not been used. The obtained results show that macroelements contained in municipal sewage sludge compost, except potassium, affected the increase of their content in test plant biomass. The manurial value of sewage sludge and composts produced with it is confirmed by the many studies carried [34, 35], which indicate that composts affect plant yield increase and their macroelements content. The organic fertiliser used in this study contained less potassium in relation to nitrogen and phosphorus. Therefore, the content of this chemical element in Amur silver grass biomass was smaller than in the objects with calcium carbonate. Furthermore, average potassium content in test plant biomass was decisively affected by the results from $2010\left(10.6 \mathrm{~g} \cdot \mathrm{kg}^{-1} \mathrm{~d} . \mathrm{m}\right.$. $)$ when compared with those from 2008 and 2009 (6.84 and $6.30 \mathrm{~g} \cdot \mathrm{kg}^{-1}$ d.m.), see Table 1.

The increasing magnesium and sulphur bioaccumulation in Amur silver grass biomass was found in the objects with municipal sewage sludge compost without and with addition of high-calcium brown coal ash. Similar results were obtained by $[36,37]$ who state that P, $\mathrm{K}, \mathrm{Mg}$ and $\mathrm{S}$ contents increase as affected by sewage sludge fertilisation. On the other hand, it results from the studies [31, 38, 39] that the factors which extremely affect differences in the content of macroelements in Amur silver grass biomass are municipal sewage sludge composts with additional mineral fertilisation. The study [40] indicate that Amur silver grass biomass is characterised by lower magnesium and calcium contents when compared with other energy plants, whereas the content of nitrogen is the highest in the first year.

Increase in the content of macroelements in Amur silver grass biomass in the objects with municipal sewage sludge compost and high-calcium brown coal ash as compared with that where only organic fertiliser had been applied may be substantiated by the effect of calcium and soil $\mathrm{pH}_{\mathrm{KCl}}$ on the intensity of microbiological processes taking place in soil. 
The enzymatic activity of soil also increased. As a result of these processes, the nutrients which had not been available for plants so far turned into assimilable forms that could be absorbed by plants. These results find confirmation in the studies [18, 41].

The obtained study results indicate that there is a correlation between compost and high-calcium brown coal ash leading to an increase in the content of nitrogen, phosphorus, calcium, magnesium and sulphur in Amur silver grass biomass.

The macroelements content in the biomass of Amur silver grass under cultivation (mean value from three harvests during three years of its cultivation) can be arranged in the following descending order: $\mathrm{K}>\mathrm{N}>\mathrm{Ca}>\mathrm{S}>\mathrm{Mg}>\mathrm{P}$.

Table 3

The content of cadmium, copper and manganese in Amur silver grass biomass in $\left[\mathrm{mg} \cdot \mathrm{kg}^{-1} \mathrm{~d} . \mathrm{m}\right.$.]

\begin{tabular}{|c|c|c|c|c|}
\hline \multirow{3}{*}{ Fertilisation objects } & \multirow{3}{*}{$\begin{array}{l}\text { Study } \\
\text { years }\end{array}$} & \multicolumn{3}{|c|}{ Chemical element } \\
\hline & & Cd & $\mathrm{Cu}$ & Mn \\
\hline & & \multicolumn{3}{|c|}{$\left[\mathrm{mg} \cdot \mathrm{kg}^{-1}\right.$ d.m. $]$} \\
\hline \multirow{3}{*}{$\begin{array}{l}\text { I. Carbonate lime }\left(\mathrm{CaCO}_{3}\right) \text { at a dose corresponding to } \\
\qquad 1.5 \mathrm{Mg} \mathrm{CaO} \cdot \mathrm{ha}^{-1}\end{array}$} & 2008 & 0.41 & 2.22 & 13.1 \\
\hline & 2009 & 0.25 & 2.12 & 13.6 \\
\hline & 2010 & 0.31 & 2.62 & 14.2 \\
\hline \multicolumn{2}{|l|}{ Mean value } & 0.32 & 2.32 & 13.6 \\
\hline \multirow{3}{*}{$\begin{array}{l}\text { II. High-calcium brown coal ash at a dose corresponding to } \\
\qquad 1.5 \mathrm{Mg} \mathrm{CaO} \cdot \mathrm{ha}^{-1}\end{array}$} & 2008 & 0.39 & 2.18 & 14.5 \\
\hline & 2009 & 0.32 & 2.08 & 13.8 \\
\hline & 2010 & 0.38 & 2.79 & 14.8 \\
\hline \multicolumn{2}{|l|}{ Mean value } & 0.36 & 2.35 & 14.4 \\
\hline \multirow{3}{*}{$\begin{array}{l}\text { III. Municipal sewage sludge compost at a dose corresponding to } \\
\qquad 250 \mathrm{~kg} \mathrm{~N} \cdot \mathrm{ha}^{-1}\end{array}$} & 2008 & 0.54 & 2.36 & 18.7 \\
\hline & 2009 & 0.49 & 2.84 & 13.8 \\
\hline & 2010 & 0.45 & 3.72 & 14.5 \\
\hline \multicolumn{2}{|l|}{ Mean value } & 0.49 & 2.97 & 15.7 \\
\hline IV. Municipal sewage sludge compost at a dose corresponding to & 2008 & 0.57 & 2.40 & 18.0 \\
\hline $250 \mathrm{~kg} \mathrm{~N} \cdot \mathrm{ha}^{-1}+$ high-calcium brown coal ash at & 2009 & 0.46 & 2.75 & 13.9 \\
\hline a dose corresponding to $1.5 \mathrm{Mg} \mathrm{CaO} \cdot \mathrm{ha}^{-1}$ (1st year of study) & 2010 & 0.57 & 3.30 & 14.9 \\
\hline \multicolumn{2}{|l|}{ Mean value } & $\mathbf{0 . 5 3}$ & 2.82 & 15.9 \\
\hline \multirow{3}{*}{$\begin{array}{l}\text { V. High-calcium brown coal ash at a dose corresponding to } \\
1.5 \mathrm{Mg} \mathrm{CaO} \cdot \mathrm{ha}^{-1} \text { (1st year of study) and to } 0.75 \mathrm{Mg} \mathrm{CaO} \cdot \mathrm{ha}^{-1} \\
\text { in following study years }\end{array}$} & 2008 & 0.40 & 2.20 & 14.6 \\
\hline & 2009 & 0.30 & 2.08 & 13.5 \\
\hline & 2010 & 0.42 & 3.85 & 14.3 \\
\hline \multicolumn{2}{|l|}{ Mean value } & $\mathbf{0 . 3 7}$ & 2.71 & 14.1 \\
\hline \multirow{3}{*}{$\begin{array}{l}\text { VI. Municipal sewage sludge compost at a dose corresponding to } \\
250 \mathrm{~kg} \mathrm{~N} \cdot \mathrm{ha}^{-1}+\mathrm{high}^{-c a l c i u m} \text { bron coal ash at a dose corresponding } \\
\text { to } 1.5 \mathrm{Mg} \mathrm{CaO} \cdot \mathrm{ha}^{-1} \text { (1st year of study) and to } 0.75 \mathrm{Mg} \mathrm{CaO} \cdot \mathrm{ha}^{-1} \\
\text { in following study years }\end{array}$} & 2008 & 0.52 & 2.38 & 18.2 \\
\hline & 2009 & 0.45 & 2.75 & 14.0 \\
\hline & 2010 & 0.52 & 3.92 & 14.8 \\
\hline \multicolumn{2}{|l|}{ Mean value } & $\mathbf{0 . 5 0}$ & 3.02 & 15.7 \\
\hline \multicolumn{2}{|l|}{ Mean value for fertilisation objects } & 0.43 & 2.69 & 14.9 \\
\hline \multicolumn{2}{|l|}{ LSD $_{0.05}$} & $\mathbf{0 . 1 0}$ & n.s. & n.s. \\
\hline
\end{tabular}

Limitations in the environmental use of municipal sewage sludges and composts produced with them may result from the excessive content of heavy metals in them $[12,42]$. While fertilising grasses with municipal sewage sludges or composts produced with them, the content of trace elements is being increased in plants [43]. When using large and very large doses of organic fertilisers $\left(40\right.$ and $60 \mathrm{Mg} \mathrm{d} . \mathrm{m} . \cdot \mathrm{ha}^{-1}$ ), an increase in the content of these elements was found in cultivated plants [44, 45].

The results obtained in this study are presented in Tables 3. The biomass of Amur silver grass contained the most cadmium, manganese and zinc in 2008 (0.47, 16.2 and 
$50.2 \mathrm{mg} \cdot \mathrm{kg}^{-1}$ d.m., respectively), the most copper in $2009\left(2.43 \mathrm{mg} \cdot \mathrm{kg}^{-1}\right.$ d.m. $)$, while the most nickel and lead in 2010 (2.6 and $3.65 \mathrm{mg} \cdot \mathrm{kg}^{-1}$ d.m., respectively). The content of heavy metals in Amur silver grass biomass, except nickel, was slightly higher when compared with the results reported by other authors [33].

The content of nickel, lead and zinc in Amur silver grass biomass in $\left[\mathrm{mg} \cdot \mathrm{kg}^{-1} \mathrm{~d} . \mathrm{m}\right.$.]

\begin{tabular}{|c|c|c|c|c|}
\hline \multirow{3}{*}{ Fertilisation objects } & \multirow{3}{*}{$\begin{array}{l}\text { Study } \\
\text { years }\end{array}$} & \multicolumn{3}{|c|}{ Chemical element } \\
\hline & & $\mathbf{N i}$ & $\mathbf{P b}$ & Zn \\
\hline & & \multicolumn{3}{|c|}{$\left[\mathrm{mg} \cdot \mathrm{kg}^{-1}\right.$ d.m. $]$} \\
\hline & 2008 & 2.08 & 3.12 & 44.0 \\
\hline 1. Carbonate lime $\left(\mathrm{CaCO}_{3}\right)$ at a dose corresponding to & 2009 & 2.04 & 3.05 & 43.1 \\
\hline & 2010 & 2.21 & 3.26 & 44.5 \\
\hline \multicolumn{2}{|l|}{ Mean value } & 2.11 & 3.14 & 43.9 \\
\hline \multirow{3}{*}{$\begin{array}{l}\text { II. High-calcium brown coal ash at a dose corresponding to } \\
\qquad 1.5 \mathrm{Mg} \mathrm{CaO} \cdot \mathrm{ha}^{-1}\end{array}$} & 2008 & 2.08 & 3.15 & 44.5 \\
\hline & 2009 & 2.05 & 3.04 & 42.3 \\
\hline & 2010 & 2.62 & 3.67 & 45.2 \\
\hline \multicolumn{2}{|l|}{ Mean value } & 2.25 & 3.29 & 44.0 \\
\hline \multirow{3}{*}{$\begin{array}{l}\text { III. Municipal sewage sludge compost at a dose corresponding to } \\
\qquad 250 \mathrm{~kg} \mathrm{~N} \cdot \mathrm{ha}^{-1}\end{array}$} & 2008 & 2.74 & 3.85 & 55.3 \\
\hline & 2009 & 2.65 & 3.78 & 51.6 \\
\hline & 2010 & 2.81 & 3.76 & 49.0 \\
\hline \multicolumn{2}{|l|}{ Mean value } & 2.73 & 3.80 & 51.9 \\
\hline IV. Municipal sewage sludge compost at a dose corresponding to & 2008 & 2.85 & 3.90 & 56.8 \\
\hline $250 \mathrm{~kg} \mathrm{~N} \cdot$ ha $^{-1}+$ high-calcium brown coal ash at a dose & 2009 & 2.78 & 3.77 & 54.1 \\
\hline corresponding to $1.5 \mathrm{Mg} \mathrm{CaO} \cdot \mathrm{ha}^{-1}$ (1st year of study) & 2010 & 2.96 & 3.95 & 55.6 \\
\hline \multicolumn{2}{|l|}{ Mean value } & 2.86 & 3.87 & 55.5 \\
\hline V. High-calcium brown coal ash at a dose corresponding to & 2008 & 2.10 & 3.18 & 43.4 \\
\hline $1.5 \mathrm{Mg} \mathrm{CaO} \cdot \mathrm{ha}^{-1}$ (1st year of study) and to $0.75 \mathrm{Mg} \mathrm{CaO} \cdot \mathrm{ha}^{-1}$ & 2009 & 2.03 & 3.11 & 42.0 \\
\hline in following study years & 2010 & 2.22 & 3.15 & 48.7 \\
\hline \multicolumn{2}{|l|}{ Mean value } & 2.11 & 3.15 & 44.7 \\
\hline $\begin{array}{l}\text { VI. Municipal sewage sludge compost at a dose corresponding to } \\
250 \mathrm{~kg} \mathrm{~N} \cdot \mathrm{ha}^{-1}+\text { high-calcium brown coal ash at a dose }\end{array}$ & 2008 & 2.75 & 3.90 & 57.0 \\
\hline corresponding to $1.5 \mathrm{Mg} \mathrm{CaO} \cdot \mathrm{ha}^{-1}$ (1st year of study) and to 0.75 & 2009 & 2.44 & 3.72 & 54.9 \\
\hline $\begin{array}{l}\mathrm{Mg} \mathrm{CaO} \cdot \mathrm{ha}^{-1} \\
\text { in following study years }\end{array}$ & 2010 & 2.82 & 4.15 & 55.7 \\
\hline \multicolumn{2}{|l|}{ Mean value } & 2.67 & 3.92 & 55.9 \\
\hline \multicolumn{2}{|l|}{ Mean value for fertilisation objects } & 4.91 & 3.53 & 49.3 \\
\hline \multicolumn{2}{|l|}{ LSD $_{0.05}$} & 0.31 & 0.57 & 5.70 \\
\hline
\end{tabular}

Average cadmium, copper, manganese, nickel, lead and zinc contents in test plant biomass were higher, respectively by $33.3,25.7,12.9,26.1,20.2$ and $23.8 \%$, in the objects where municipal sewage sludge compost had been applied without and with addition of high-calcium brown coal ash (fertilisation objects III, IV and VI) when compared with those where only calcium carbonate or high-calcium brown coal ash had been introduced into soil (fertilisation objects I and II); see Tables 3 and 4.

The biomass of Amur silver grass contained significantly more cadmium, nickel, lead and zinc as affected by organic fertilisation without and with addition of high-calcium brown coal ash when compared with the objects where solely calcium carbonate or high-calcium brown coal ash had been introduced into soil at a dose of $1.5 \mathrm{Mg} \mathrm{CaO} \cdot \mathrm{ha}^{-1}$. Differences in the average content of cadmium, nickel and zinc in test plant biomass from 
the objects fertilised with municipal sewage sludge compost without and with addition of high-calcium brown coal ash were not significant (Tables 3 and 4).

More copper and manganese was contained by Amur silver grass biomass from the objects fertilised with municipal sewage sludge compost without and with addition of high-calcium brown coal ash (fertilisation objects II, IV and VI) when compared with those where high-calcium brown coal ash or calcium carbonate had been applied (fertilisation objects I, II and V). Differences in content of copper and manganese in Amur silver grass biomass in particular fertilisation objects were not significant (Table 3) even though the average increase in the content of chemical elements under discussion between these fertilisation objects amounted respectively to 19.1 and $12.3 \%$. The content of heavy metals in Amur silver grass biomass observed in the carried out study barely differ from that reported by other authors [30]. Their content was in the range of physiological concentrations.

The value of heavy metals uptake by Amur silver grass biomass depended on the yield size and their content. The total uptake of heavy metals concerned is compared in Table 5.

Table 5

Total cadmium, copper, manganese, nickel, lead and zinc uptake by Amur silver grass biomass in 2008-2010. Data are given in $\left[\mathrm{g} \cdot \mathrm{ha}^{-1} \mathrm{~d} . \mathrm{m}.\right]$

\begin{tabular}{|c|c|c|c|c|c|c|}
\hline \multirow{3}{*}{$\begin{array}{c}\text { Fertilisation } \\
\text { objects }\end{array}$} & \multicolumn{6}{|c|}{ Chemical element } \\
\hline & Cd & $\mathbf{C u}$ & Mn & $\mathrm{Ni}$ & $\mathbf{P b}$ & Zn \\
\hline & \multicolumn{6}{|c|}{$\left[\mathrm{g} \cdot \mathrm{kg}^{-1}\right.$ d.m.] } \\
\hline I & 8.61 & 71.5 & 411.3 & 63.2 & 93.8 & 1297 \\
\hline II & 9.73 & 75.3 & 431.2 & 71.7 & 102.5 & 1319 \\
\hline III & 16.5 & 117.9 & 507.4 & 96.8 & 132.8 & 1768 \\
\hline IV & 18.9 & 109.5 & 523.4 & 103.3 & 138.7 & 1968 \\
\hline $\mathrm{V}$ & 12.1 & 102.4 & 451.2 & 69.1 & 100.9 & 1486 \\
\hline VI & 18.7 & 129.7 & 554.6 & 83.5 & 150.9 & 2104 \\
\hline Mean & 14.1 & 101.0 & 479.8 & 81.3 & 119.9 & 1657 \\
\hline $\mathbf{L S D}_{0.05}$ & 0.06 & 0.16 & 0.18 & 2.10 & 0.22 & 16.2 \\
\hline
\end{tabular}

* Description of fertilisation objects is given in Table 1 .

The total uptake of heavy metals by Amur silver grass biomass from the objects fertilised with municipal sewage sludge compost without and with addition of high-calcium brown coal ash being applied at the beginning of study and annually (fertilisation objects III, IV and V) increased on average by $96.7 \%$ for cadmium, $62.2 \%$ for copper, $48.8 \%$ for zinc, $46.0 \%$ for nickel, $43.4 \%$ for lead and $25.4 \%$ for manganese (Table 5) when compared with that fertilised with calcium carbonate or high-calcium brown coal ash (fertilisation objects I and II).

As a result of organic fertilisation without and with addition of high-calcium brown coal ash being applied at the beginning of study and annually (fertilisation objects III, IV and VI), the uptake of cadmium, copper, manganese, nickel, lead and zinc by Amur silver grass biomass increased significantly when compared with fertilisation objects I and II. Significant increase in the uptake of manganese, nickel, lead and zinc by test plant biomass was observed in the objects fertilised with high-calcium brown coal ash when compared with that where carbonate lime had been introduced into soil (Table 5). 
The effect of fertilisation with calcium carbonate, high-calcium brown coal ash and municipal sewage sludge compost on the total uptake of cadmium, copper, manganese, nickel, lead and zinc by Amur silver grass biomass differed. The largest copper, manganese, lead and zinc uptake related to the objects fertilised with municipal sewage sludge compost with addition of high-calcium brown coal ash being applied in the first year of study and in following study years. During three study years, test plant biomass absorbed significantly less heavy metals concerned from the objects fertilised with calcium carbonate or high-calcium brown coal ash when compared with those where organic fertilisation without and with addition of high-calcium brown coal ash had been applied.
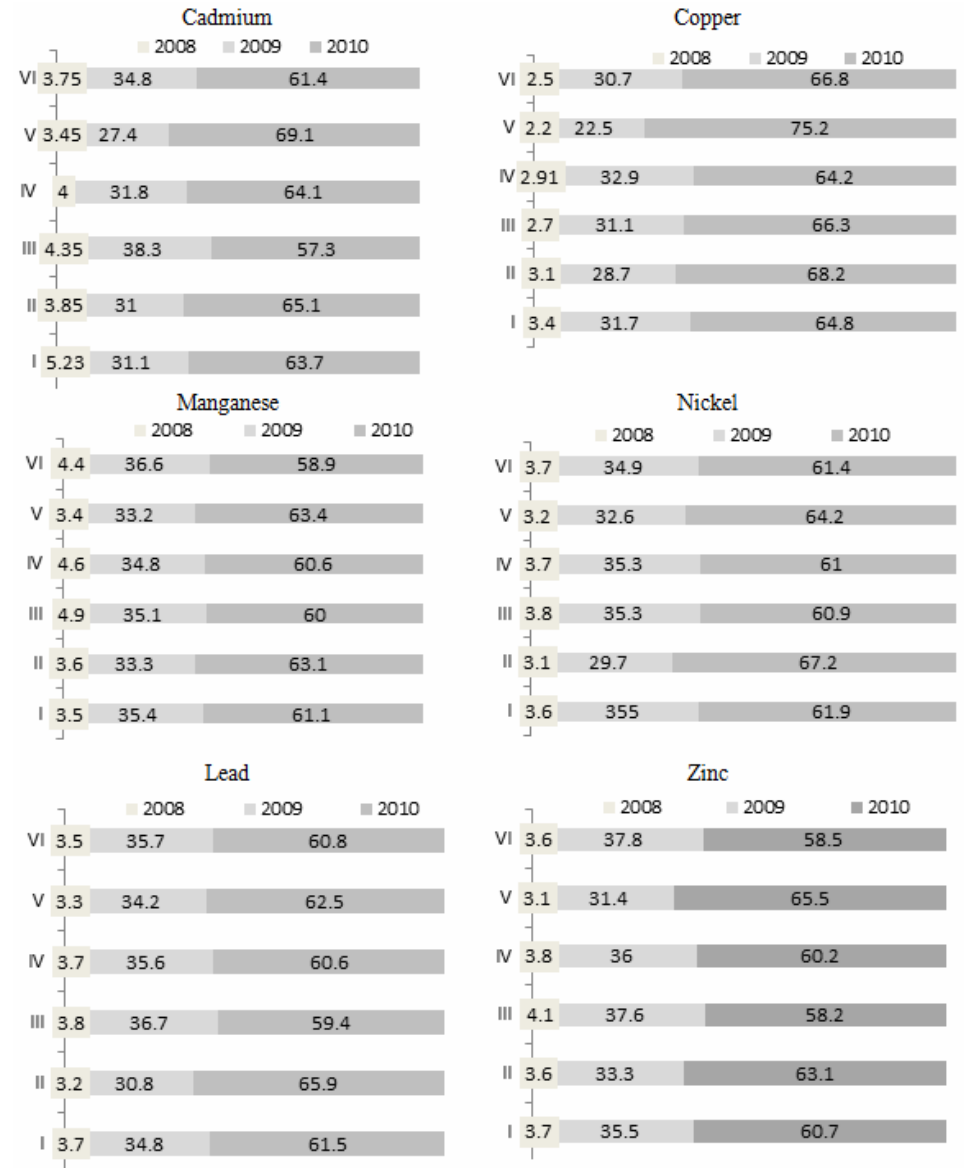

Fig. 1. Dynamics of heavy metals uptake by Amur silver grass biomass in successive years of cultivation in relative values (total uptake $=100 \%$ ). Description of fertilisation objects (I to VI) is given in Table 1

The analysed heavy metals are characterised by different mobility in soil environment and phytoavailability, which is being determined by the properties of heavy metals themselves as well as by soil properties and plant characteristics [46, 47]. 
The total uptake of chemical elements under discussion by Amur silver grass biomass was the smallest in fertilisation objects I and II. When analysing the dynamics of heavy metals uptake, it was found to be decidedly smaller in the first year of study and ranged from 2.25 to $5.23 \%$. It increased in the second year of study, being within the limits of 22.5 to $38.0 \%$, while reached the largest values in the third year of study, oscillating between 57.3 and $69.4 \%$ (Fig. 1). Similar study results were obtained by Izewska [31].

The uptake of heavy metals by Amur silver grass biomass, ie its mean value of three harvest during three years of its cultivation, can be arranged in the following descending order of values: $\mathrm{Zn}>\mathrm{Mn}>\mathrm{Pb}>\mathrm{Cu}>\mathrm{Ni}>\mathrm{Cd}$. Slightly different study results were obtained by researchers who found that the quantity of heavy metals absorbed by plants could be presented as the following series: $\mathrm{Zn}>\mathrm{Cd}>\mathrm{Ni}>\mathrm{Cu}>\mathrm{Pb}=\mathrm{Cr}[48,49]$. It results from the study conducted on Indian bread shot fertilised with sewage sludge that the amount of heavy metals being absorbed by plants is arranged in the following series: $\mathrm{Cu}>\mathrm{Cr}>\mathrm{Fe}>\mathrm{Mn}=\mathrm{Pb}>\mathrm{Cd}>\mathrm{Ni}[50]$. This order is slightly different when compared with that in the experiment under discussion. Small uptake of copper $\left(101.0 \mathrm{~g} \cdot \mathrm{ha}^{-1}\right)$ and nickel $\left(81.3 \mathrm{~g} \cdot \mathrm{ha}^{-1}\right)$ by Amur silver grass biomass during three study years should be explained by the bonding of chemical elements under discussion by organic matter and the formation of chelate bonds in soil. Furthermore, heavy metals that have been found in ashes get into the trophic chain due to their low solubility and weak metabolic barrier being characteristic of plants [51].

The biomass of Amur silver grass did not absorbed excessive quantities of cadmium, copper, manganese, nickel, lead and zinc since they had not been brought into soil with municipal sewage sludge compost and high-calcium brown coal ash in considerable amounts, whereas the soil itself did no contain their excessive amounts.

When evaluating the usefulness of Amur silver grass biomass for using heavy metals from the compost produced with municipal sewage sludge and high-calcium brown coal ash, cadmium, copper, manganese, nickel, lead and zinc bioaccumulation factors were calculated.

Table 6

Bioaccumulation factors for heavy metals in Amur silver grass biomass in 2008-2010 as affected by municipal sewage sludge compost and high-calcium brown coal ash

\begin{tabular}{|c|c|c|c|c|c|c|}
\hline \multirow{2}{*}{$\begin{array}{c}\text { Fertilisation } \\
\text { objects }\end{array}$} & \multicolumn{6}{|c|}{ Chemical element } \\
\hline & Cd & $\mathbf{C u}$ & Mn & $\mathbf{N i}$ & $\mathbf{P b}$ & Zn \\
\hline II & $\frac{1.690}{\text { intense }}$ & $\underline{1.077}$ & $\underline{0.688}$ & $\frac{2.261}{\text { intense }}$ & $\frac{2.570}{\text { intense }}$ & $\frac{2.410}{\text { intense }}$ \\
\hline III & $\underline{1.144}$ & $\underline{\underline{0.154}}$ average & $\underline{\underline{0.148}}$ & $\underline{\underline{0.780}}$ & $\frac{1.727}{\text { intense }}$ & $\underline{\underline{0.908}}$ \\
\hline IV & $\underline{\underline{0.826}}$ & $\underline{\underline{0.131}}$ average & $\frac{0.125}{\text { average }}$ & $\underline{\underline{0.636}}$ & $\frac{1.112}{\text { average }}$ & $\underline{\underline{0.736}} \underline{\text { average }}$ \\
\hline $\mathrm{V}$ & $\frac{1.170}{\text { intense }}$ & $\underline{\underline{0.836}}$ & $\frac{0.452}{\text { average }}$ & $\frac{1.425}{\text { intense }}$ & $\frac{1.657}{\text { intense }}$ & $\frac{1.647}{\text { intense }}$ \\
\hline VI & $\underline{\underline{0.886}}$ & $\underline{\underline{0.134}} \underline{\text { average }}$ & $\frac{0.114}{\text { average }}$ & $\underline{\underline{0.536}}$ & $\begin{array}{l}\underline{0.956} \\
\text { average }\end{array}$ & $\underline{\underline{0.663}} \underline{\text { averagge }}$ \\
\hline Mean value & $\underline{1.143}$ & $\begin{array}{c}\text { 0.467 } \\
\text { average }\end{array}$ & $\frac{0.306}{\text { average }}$ & $\underline{1.127}$ & $\underline{\text { intense }}$ & $\underline{1.273}$ \\
\hline
\end{tabular}

* Description of fertilisation objects is given in Table 1. 
The degree of cadmium, copper, manganese, nickel, lead and zinc bioaccumulation in Amur silver grass biomass differed, depending on the fertilisation applied. When calculating the bioaccumulation factor, fertilisation object I, where municipal sewage sludge compost nor high-calcium brown coal ash had not been applied, was omitted (Table 6).

The degree of cadmium, copper, nickel, lead and zinc accumulation in Amur silver grass biomass after three study years was intense in the object with high-calcium brown coal ash being applied at a dose corresponding to $1.5 \mathrm{Mg} \mathrm{CaO} \cdot \mathrm{ha}^{-1}$, whereas average for manganese (0.826). In the object with high-calcium brown coal ash being introduced into soil at a dose corresponding to $1.5 \mathrm{Mg} \mathrm{CaO} \cdot \mathrm{ha}^{-1}$ in the first year of study and to $0.75 \mathrm{Mg} \mathrm{CaO} \cdot \mathrm{ha}^{-1}$ in following study years, an intense degree of accumulation was found in case of cadmium, nickel, lead and zinc, whereas an average one for other heavy metals (Table 6). Intense accumulation degree was characteristic of cadmium (1.144) and lead (1.727) in the object with organic fertilisation being excluded (fertilisation object III), while an average one of other heavy metals. In the object with municipal sewage sludge compost being introduced into soil at a dose of $250 \mathrm{~kg} \mathrm{~N} \cdot \mathrm{ha}^{-1}$ and high-calcium brown coal ash at a dose corresponding to $1.5 \mathrm{Mg} \mathrm{CaO} \cdot \mathrm{ha}^{-1}$ in the first year of study, the accumulation degree for cadmium, manganese, nickel, lead and zinc in test plant biomass was average. It was also found that the higher the content of a given heavy metal being brought into soil with municipal sewage sludge compost without and with addition of high-calcium brown coal ash, the smaller the bioaccumulation factor in Amur silver grass biomass.

The accumulation degree of heavy metals in test plant biomass after three study years reached an intense and an average level.

The reason of average heavy metals bioaccumulation Amur silver grass biomass was alkaline reaction of municipal sewage sludge compost $(\mathrm{pH} 8.50)$ and high-calcium brown coal ash $\left(\mathrm{pH}_{\mathrm{KCl}} 11.0\right)$, which induced a weak mobility of these chemical elements and their small sorption. Heavy metals form chelate complexes with organic matter in soil, the bond strength of which increases together with an increase in soil $\mathrm{pH}[52,53]$. On the other hand, high-calcium brown coal ashes did not have a negative effect on chemical and biological processes taking place in soils [54].

The average degree of heavy metals accumulation may be the result of organic matter introduction with compost and increased soil sorption capacity [56]. Large group of authors are of the opinion that complexing properties increase in the soil being fertilised with sewage sludge or composts produced with them, owing to which stable metal-organic associations are formed that limit the availability of heavy metals for plants.

\section{Conclusions}

1. Amur silver grass biomass contained on average the most nitrogen, ie $6.87 \mathrm{~g} \mathrm{~N} \cdot \mathrm{kg}^{-1}$ d.m., in 2008 , while the most phosphorus ( $0.39 \mathrm{~g} \mathrm{P} \cdot \mathrm{kg}^{-1} \mathrm{~d} . \mathrm{m}$.), potassium (7.82 $\left.\mathrm{g} \mathrm{K} \cdot \mathrm{kg}^{-1} \mathrm{~d} . \mathrm{m}.\right)$, magnesium $\left(0.98 \mathrm{~g} \mathrm{Mg} \cdot \mathrm{kg}^{-1} \mathrm{~d} . \mathrm{m}.\right)$ and sulphur (1.19 $\mathrm{g} \mathrm{S}^{\mathrm{kg}} \mathrm{kg}^{-1} \mathrm{~d} . \mathrm{m}$.) in 2010 , whereas the most calcium, ie $4.13 \mathrm{~g} \mathrm{Ca} \cdot \mathrm{kg}^{-1} \mathrm{~d} . \mathrm{m}$., in 2009.

2. Municipal sewage sludge compost without and with high-calcium brown coal ash contributed to the increase of average nitrogen, phosphorus, calcium, magnesium and sulphur contents in Amur silver grass, respectively by 15.6, 50.0, 32.7, 16.2 and 37.2\%, when compared with the fertilisation object with calcium carbonate. 
3. Significantly more nitrogen, calcium and sulphur was contained by Amur silver grass biomass from the objects where municipal sewage sludge compost had been applied without and with addition of high-calcium brown coal ash when compared with calcium carbonate or high-calcium brown coal ash being introduced into soil at the beginning of study.

4. Differences in average phosphorus, potassium and magnesium contents in test plant biomass from particular fertilisation objects were not significant.

5. The macroelements content in the biomass of Amur silver grass under cultivation (mean value of three harvests during three years of its cultivation) can be arranged in the following descending order: $\mathrm{K}>\mathrm{N}>\mathrm{Ca}>\mathrm{S}>\mathrm{Mg}>\mathrm{P}$.

6. Average cadmium, copper, manganese, nickel, lead and zinc contents in test plant biomass were higher, respectively by $33.3,25.7,12.9,26.1,20.2$ and $23.8 \%$, in the objects where municipal sewage sludge compost had been applied without and with addition of high-calcium brown coal ash when compared with those where only calcium carbonate or high-calcium brown coal ash had been introduced into soil.

7. The biomass of Amur silver grass did not absorbed excessive quantities of heavy metals since they had not been brought into soil with municipal sewage sludge compost and high-calcium brown coal ash in considerable amounts, whereas the soil itself did no contain their excessive amounts.

8. The accumulation degree of heavy metals in Amur silver grass biomass after three study years reached an intense and an average level.

\section{Acknowledgement}

Part of this study was conducted within the framework of a research and development project No. 0397/R/P01/2008/04 funded by the National Centre for Research and Science.

\section{References}

[1] Aggelides SM, Londra PA. Effects of compost produced from town wastes and sewage sludge on the physical properties of a loamy and a clay soil. Bioresour Technol. 2000;71(3):253-259. DOI: 10.1016/S0960-8524(99)00074-7.

[2] Carbonell G, Imperial RM, Torrijos M, Delgado M. Effects of municipal solid waste compost and mineral fertilizer amendments on soil properties and heavy metals distribution in maize plants. Chemosphere. 2011;85(10):1614-1623. DOI:101016/j.chemosphere.2011.08.025.

[3] Li H, Wang Y, Weixiang W, Murray B, McBride Y, Chen J. Biomass and Cu and Zn uptake of two Turfgrass species grown in sludge compostsoil mixtures. Water Air Soil Pollut. 2007;188(1-4):225-234. DOI: $10.1007 / \mathrm{s} 11270-007-9539-1$.

[4] Jasiewicz C, Antoniewicz J, Mazur Z, Krajewski W. Agrochemical properties of soil fertilized with sewage sludge from sewage treatment plant at Olecko. Ecol Chem Eng. 2007;14(5-6):457-463.

[5] Harrison EZ, Oakes SR, Hysell M, Hay A. Organic chemical in sewage sludge. Sci of the Rotal Environ. 2006;367:481-497. DOI: 10.1016/j.scitotenv.2006.04.002.

[6] Korboulewsky N, Dupouyet S, Bonin G. Environmental risks of applying sewage sludge compost to vineyards. J Environ Qual. 2002;31:1522-1527. DOI:10.2134/JEQ2002.1522.

[7] Czekała J. Właściwości chemiczne kompostu wytworzonego z komunalnego osadu ściekowego i różnych bioodpadów. J Res Appl Agric Eng. 2008;53(3):35-41.

[8] Roca-Perez L, Martinez C, Marcilla P, Boluda R. Composting rice straw with sewage sludge and compost effects on the soil-plant system. Chemosphere. 2009;75(6):58-65.DOI:10.1016/j.chemosphere. 2008.12.058.

[9] Cai Q-Y, Mo C-H, Wu Q-T, Zeng Q-Y, Katsoyiannis A. Concentration and speciation of heavy metals in six different sewage sludge-composts. J Hazard Mat. 2007;147:1063-1072. DOI: 10.1016/j.jhazmet.2007.01.142. 
[10] Haroun M., Idris A., Syed Omar S.R. Characterisation and composting of tanery sludge. Malaysian J. Soil Sci. 2007;11:71-80. DOI:10.1016/j.wasman.2006.09.006.

[11] Rozporządzenie Ministra Środowiska w sprawie komunalnych osadów ściekowych DzU 10.137.924.

[12] Torri SI, Lavado R. Zinc distribution in soils amended with different kinds of sewage sludge. J Environ Manage. 2008;88(4):1571-1579. DOI: 10.1016/j.jenvman.2007.07.026.

[13] Tracy D, Baker B. Heavy metals in fertilizers used in organic production. www. omri. b6-205-02-14.pdf, 2005, Org. Metales in Fertilizers.

[14] Kabata-Pendias A, Pendias H. Trace Elements in Soils and Plants. (3rd ed.) CRC Press. 2000, 4-13.

[15] Antonkiewicz J. Influence of various ash-sludge and ash-peat mixtures on quantity and quality of maize yield. Cz. III. Heavy metals. Chem Inż Ekol. 2007;14(3-4):265-274.

[16] Staisz J, Pasoń-Konieczyńska A, Konieczyński J. Wstępna ocena emisji pierwiastków śladowych w wyniku spalania węgla kamiennego. Arch Ochr Środ. 2000;26(1);7-20.

[17] Kwiatkowska B, Cierpiszewski R, Domka F. The impact of acid precipitation on the texture of fly ash and bioavailable metals. Ekol Techn. 2006;14(2):53-58

[18] Stankowski S, Gibczyńska M, Bielińska EJ, Szczygielski T, Kanafek J. Popioły z energetyki - ocena przydatności do celów nawozowych. Puławy: Wyd UPS; 2006:7-35.

[19] Gibczyńska M, Meller E, Hury G. Oddziaływanie popiołu z węgla brunatnego na wybrane właściwości fizyczno-chemiczne gleby lekkiej. Zesz Probl Post Nauk Roln. 2007;518:53-61.

[20] Quant B. Przeciwdziałanie negatywnemu oddziaływaniu składowisk odpadów paleniskowych na otoczenie Z wykorzystaniem osadów ściekowych. Ekol Techn. 2000;8(4):95-99.

[21] Maciejewska A, Wrońska D. Zagospodarowanie mieszanin osadowo-popiołowych w świetle literatury, obowiązujące prawa i praktyki. In: Obieg pierwiastków w przyrodzie. Monografia, t. 2. Gworek B, Misiak J, editors. Warszawa: Dział Wyd IOŚ; 2003;634-642.

[22] Kovàcik P, Macàk M, Ducsay L, Halcćinovà M, Janćich M. Effect of ash-fly ash mixture application on soil fertility. J. Elem. 2011; 16(2):215-225. DOI: 10.5601/jelem.2011.16.2.05.

[23] Antonkiewicz J. Effect of ash-sludge mixtures and peat ash on the yield of grass mixtures Birdsfoot trefoil and the contents of selected elements in the mix. Acta Sci Polon Formatio Circumiectus. 2007;6(3):61-72.

[24] Rozporządzenie Ministra Rolnictwa i Rozwoju Wsi z dnia 18 czerwca 2008 r. w sprawie wykonywania niektórych przepisów ustawy o nawozach i nawożeniu. DzU.08.119.765.

[25] Rocznik Statystyczny Rzeczpospolitej Polski. Warszawa: GUS; 2010.

[26] Blumberg M, Bach G, Baldin K. Berichte $\mathrm{zu}$ der Veranstaltung Energieseminar an der TU-Berlin Rottetrommel. Adenda 21 und Abfalentlentsorgung. Berlin: Walter de Gruyter; 2004.

[27] Kuo S, Ortiz-Escobar ME, Hue NV, Hummel RL. Composting and compost utylization for agronomic and container crops. Recent Res Devel Environ Biol. 2004;(I):415-531.

[28] Cherif H, Ayari F, Quazari H, Marzorati M, Brusetti L, Jedidi N, Hassen A, Daffonchio D. Effects of municipal solid waste compost, farmyard manure and chemical fertilizers on wheat growth, soil compositiation and soil bacterial characteristics under Tunisian arid elimate. Europ J Soil Biol. 2009; 45:138-145. DOI: 10.1016/j.ejsobi 2008.11.003.

[29] Krzywy-Gawrońska E. The effect of industrial wastes and municipal sewage sludge compost on the quality of virginia fanpetals (Sida hermaphrodita Rusby) biomass. Part 1. Macroelements content and their uptake dynamics. Polish J Chemical Technology. 2012;14(2), 9-15. DOI: 10.2478/v10026-012-0064-7.

[30] Migaszewski ZM, Gałuszka A. Podstawy geochemii środowiska. Warszawa: Wyd. NT; 2007;195-269.

[31] Iżewska A., Przydatność kompostów z komunalnego osadu ściekowego do nawożenia miskanta cukrowego Miscanthus sacchariflorus (Maxim.) Hack. Szczecin: Wyd ZUT w Szczecinie. 2009; 108.

[32] Kuś J, Matyka M. Wybrane elementy uprawy roślin na cele energetyczne. Nowoczesne technologie pozyskiwania i energetycznego wykorzystania biomasy. Monografia. Wyd. Instytut Energetyki; 2010;101-120.

[33] Łabętowicz J, Stępień W. Nawożenie roślin energetycznych (wierzba, miskant, ślazowiec). Nowoczesne technologie pozyskiwania i energetycznego wykorzystania biomasy. Monografia. Wyd. Instytut Energetyki; 2010;89-100.

[34] Kiryluk A. Wpływ osadu ściekowego na produkcję biomasy roślinnej i zawartość makroelementów w mieszankach rekultywacyjnych traw. Zesz Probl Post Nauk Roln. 2003;494:167-173.

[35] Kalembasa D, Malinowska E. Wpływ dawek osadu ściekowego na plon i skład chemiczny traw Miscanthus sacchariflorus. Fragm Agron. 2007;24(93):113-117.

[36] Kalembasa D, Malinowska E. Wpływ dawek osadu ściekowego na plon biomasy trawy Miscanthus sacchariflorus (Maxim.) Hack, zawartość siarki oraz wartość energetyczną. Zesz Probl Post Nauk Roln. 2008;533:173-179. 
[37] Kalembasa D, Malinowska E. Zawartość makroskładników w biomasie trawy Miscanthus sacchariflorus (Maxim.) Hack. oraz w glebie po trzech latach uprawy. Zesz Probl Post Nauk Roln. 2009;537:153-161.

[38] Stasiak M. Trawa Miscanthus sacchariflorus jako roślina wykorzystywana w bioremediacji i energii odnawialnej In: Biotechnologia środowiska. Materiały XIII Ogólnopolskiego Seminarium Studentów i Doktorantów, Wisła-Jarzębata 8-10 grudnia 2006. Gliwice: Wyd. Polit Śl. 2006;171-175.

[39] Tworkowski J, Stolarski M, Wróblewska H., Skład chemiczny i wartość energetyczna biomasy wierzby krzewiastej, ślazowca pensylwańskiego i miskanta olbrzymiego. Zesz Probl Post Nauk Roln. 2010;547:401-408.

[40] Maciejewska A. Węgiel brunatny jako źródło substancji organicznej i jego wpływ na właściwości gleb. Warszawa: Wyd Politech Warszawska; 1998;52-67.

[41] Wysokiński A, Kalembasa S. Wybrane parametry fizyczno chemiczne świeżych i kompostowanych osadów ściekowych oraz ich mieszanin z CaO lub popiołem z węgla brunatnego Acta Sci Pol Formatio Circumietus, 2006;5(1):51-61.

[42] Li S, Zhang K, Zhou S, Zhang L, Chen Q. Use of dewatered municipal sludge on Canna growth in pot experiments with a barren clay soil. Waste Manage. 2009; 29(6):1870-1876. DOI: 10.1016/j.wasman.2008.12.07

[43] Jasiewicz C, Antonkiewicz J, Baran S. Influence of organic fertilizers on heavy metal content in tall oat grass. Ecol Chem Eng. 2006;13(9):915-923.

[44] Mohammad MJ, Athamneh M. Changes in soil fertility and plant uptake of nutrients and heavy metals in response to sewage sludge application to calcareous soil. J Agron. 2004;3(3):229-236.

[45] Wang P, Zhang S, Wang C, Hou J, Guo P, Lin Z. Study of heavy metal in sewage sludge and in Chinese cabbage grown in soil amended with sewage sludge. African J Biotechnol. 2008;7(9):1329-1334.

[46] Grabas K, Kołwzan B, Gediga K, Spiak Z. Bioaccumulation of trace elements in some plant species growing in the under environmental effect of the Kowary mine tailing pond. Pol $\mathrm{J}$ Environ Stud. 2006;15(2): 273-280.

[47] Kozanecka T, Czarnowska K, Brogowski Z, Kwsowski W. Content of microelements in selected herbs natural meadows. Pol J Environ Stud. 2006;15(2): 385-389.

[48] Hua L, Wu W, Liu Y, McBribe MB, Chen Y. Reduction of nitrogen loss and Cu and Zn mobility during sludge composting with bamboo charcoal amendment. Environ Sci Pollut Res Int. 2009;16(1):1-9. DOI: 10.1007/s11356-008-0041-0.

[49] Hargreaves JC, Adl MS, Warman PR. A review of the use of composted municipal solid waste in agriculture. Agric. Ecosys. Environ. 2008;123: 1-14. DOI. 10.1016/j.agee.2007.07.004.

[50] Bose S, Jain A, Rai V, Ramanathan AL. Chemical fractionation and translocation of heavy metals in Canna indica L. grown on industrial soil. J Hazard Mater. 2008;160:187-193. DOI: 0.1016/j.jhazmat.2008.02.119.

[51] Liu J, Xiong Z, Li T, Huang H. Bioaccumulation and ecophysiological responses to copper stress in two populations of Rumex dentaus $\mathrm{L}$., from $\mathrm{Cu}$ contaminated and noncontaminated sites. Environ Exp Bot. 2004;52:43-51. DOI:10.1016/j.envexploat.2004.01.005.

[52] Gorlach E, Gambuś F, Michniak A. The effect of $\mathrm{pH}$ on the uptake of heavy metals by Italian ryegrass (Lolium multiflorum) in the conditions of their differentiated contents in soil. Pol J Soil Sci. 1990;23(1):17-23.

[53] Randal SS, Bruce RJ. Zinc sorption by B Horizon soil as a function of pH. Soil Sci Soc Am J. 1991;55:1592-1597.

[54] Gilewska M. Przetwarzanie i wykorzystanie popiołów wysokowapniowych. Parametry jakościowe węgla brunatnego i popiołów powstających w wyniku jego spalania w elektrowni. Materiały Międzynarodowego Seminarium Naukowo-Technicznego. Bełchatów: Wyd Ekotech Bełchatów. 2006;285-293.

[55] Eriksson E, Christensen N, Schmidt JF, Ledin A. Potential priority pollutants in sewage sludge. Elsevier. 2008;226:371-388. DOI: 10.1016/j.desol.2007.03.019.

[56] Flis-Bujak M, Baran S, Żukowska G. Właściwości materii organicznej wybranych odpadów o charakterze nawozowym. Zesz Probl Post Nauk Roln. 1996;437:147-153. 


\title{
OCENA ODDZIAŁYWANIA KOMPOSTU Z KOMUNALNEGO OSADU ŚCIEKOWEGO I ODPADÓW PALENISKOWYCH NA JAKOŚĆ BIOMASY MISKANTA CUKROWEGO (MISCANTHUS SACHARIFLORUS)
}

\author{
Zakład Rekultywacji i Chemii Środowiska \\ Zachodniopomorski Uniwersytet Technologiczny w Szczecinie
}

\begin{abstract}
Abstrakt: Doświadczenie polowe jednoczynnikowe przeprowadzono w latach 2008-2010 w Stacji Oceny Odmian w Szczecinie - Dąbiu. Gleba, na której założono doświadczenie, wytworzona została z piasku gliniastego lekkiego (pgl). Pod względem składu granulometrycznego zalicza się ją do kategorii gleb lekkich, kompleksu przydatności rolniczej IV b, żytniego dobrego. W doświadczeniu użyto kompostu wyprodukowanego z udziałem komunalnego osadu ściekowego metodą GWDA. Kompost ten zawierał wyraźnie więcej azotu i fosforu w stosunku do potasu. Zawartość metali ciężkich (Cd, $\mathrm{Cu}, \mathrm{Mn}, \mathrm{Ni}, \mathrm{Pb}$ i $\mathrm{Zn}$ ) w kompostach nie przekraczała norm z Rozporządzenia Ministra Rolnictwa i Rozwoju Wsi (DzU.08.165.765) dotyczących nawozów organicznych. W schemacie badań zastosowano następujące kombinacje nawozowe: I - wapno węglanowe $\left(\mathrm{CaCO}_{3}\right)$ w dawce $1,5 \mathrm{Mg} \mathrm{CaO} \cdot \mathrm{ha}^{-1}$, II - wysokowapniowy popiół z węgla brunatnego w dawce $1,5 \mathrm{Mg} \mathrm{CaO} \cdot \mathrm{ha}^{-1}$, III - kompost $\mathrm{z}$ komunalnego osadu ściekowego w dawce $250 \mathrm{~kg} \mathrm{~N} \cdot \mathrm{ha}^{-1}$, IV - kompost $\mathrm{z}$ komunalnego osadu ściekowego w dawce $250 \mathrm{~kg} \mathrm{~N} \cdot \mathrm{ha}^{-1}+$ wysokowapniowy popiół z węgla brunatnego w dawce $1,5 \mathrm{Mg} \mathrm{CaO} \cdot \mathrm{ha}^{-1}$ (I rok badań), $\mathrm{V}$ - wysokowapniowy popiół $\mathrm{z}$ węgla $\cdot \mathrm{ha}^{-1}$. Dodatkowo corocznie stosowano nawożenie mineralne w postaci Polifoski 20, Polimagu S i saletry amonowej. Rośliną testową była wieloletnia trawa miskant cukrowy (Miscanthus sachariflorus). Uzyskane rezultaty wskazują, że biomasa miskanta cukrowego zawierała średnio najwięcej azotu $-6,87 \mathrm{~g} \cdot \mathrm{kg}^{-1}$ s.m. w 2008 roku, a fosforu $-0,39 \mathrm{~g} \cdot \mathrm{kg}^{-1}$ s.m., potasu $-7,82 \mathrm{~g} \cdot \mathrm{kg}^{-1}$ s.m., magnezu - $0,98 \mathrm{~g} \cdot \mathrm{kg}^{-1}$ s.m. i siarki - $1,19 \mathrm{~g} \cdot \mathrm{kg}^{-1}$ s.m. w 2010 roku. Natomiast wapnia w 2009 roku $4,13 \mathrm{~g} \cdot \mathrm{kg}^{-1} \mathrm{~s} . \mathrm{m}$. Istotnie więcej azotu, wapnia i siarki zawierała biomasa miskanta cukrowego z obiektów, w których stosowano kompost bez i z dodatkiem wysokowapniowego popiołu z węgla brunatnego w porównaniu z węglanem wapnia lub wysokowapniowym popiołem $\mathrm{z}$ węgla brunatnego stosowanymi w dawce $1,5 \mathrm{Mg} \mathrm{CaO}$. ha ${ }^{-1}$. Różnice w średniej zawartości fosforu, potasu i magnezu w biomasie rośliny testowej z poszczególnych obiektów nawozowych nie były istotne. Biomasa miskanta cukrowego pod wpływem nawożenia organicznego bez i z dodatkiem wysokowapniowego popiołu z węgla brunatnego zawierała istotnie więcej kadmu, niklu, ołowiu i cynku w porównaniu z obiektami, w których do gleby wprowadzono wyłącznie węglan wapnia lub wysokowapniowy popiół z węgla brunatnego. Różnice w średniej zawartości kadmu, niklu i cynku w biomasie rośliny testowej z obiektów nawożonych kompostem bez i z dodatkiem popiołu z wysokowapniowego węgla brunatnego nie były istotne. Pobranie metali ciężkich przez biomasę miskanta, średnia z trzech zbiorów w ciągu trzech lat uprawy, układała się w następującym szeregu malejących wartości: $\mathrm{Zn}>\mathrm{Mn}>\mathrm{Pb}>\mathrm{Cu}>\mathrm{Ni}>\mathrm{Cd}$. Stopień bioakumulacji metali ciężkich w biomasie rośliny testowej był zróżnicowany w zależności od zastosowanego nawożenia. Średni stopień akumulacji po trzech latach badań dla wszystkich obiektów nawozowych dla kadmu, niklu, ołowiu i cynku był intensywny, a miedzi i manganu średni.
\end{abstract}

Słowa kluczowe: kompost, węglan wapnia, wysokowapniowy popiół z węgla brunatnego, miskant cukrowy, zawartość makroskładników, pobranie i bioakumulacja metali ciężkich 